\title{
Fructose- and Iron-Mediated Model of Steatohepatitis in Rats
}

\section{Sıçanlarda Fruktoz ve Demir Aracılı Steatohepatit Modeli}

\section{Muharrem Keskin ${ }^{1}$,}

${ }^{1}$ Necmettin Erbakan University, Meram Faculty of Medicine, Department of Gastroenterology, Konya, Turkey

Geliş Tarihi/Received: 4 February 2019 Kabul Tarihi/Accepted: 27 March 2019

Address correspondence to: Muharrem Keskin, Necmettin Erbakan University, Meram Faculty of Medicine, Department of Gastroenterology, Konya, Turkey e-mail: muharrem.keskin@gmail.com

\section{ORCID}

Muharrem Keskin

https://orcid.org/0000-0002-5696-4752

\begin{abstract}
Öz
Amaç: Bu çalışmada, sıçanlarda fruktoz ve demir aracılığıyla insan fenotipine yakın bir steatohepatit modeli oluşturulması amaçlanmıştır.

Gereçler ve Yöntem: Çalışmada 90 adet 1,5-2 aylık Wistar-Albino cinsi dişi sıçanlar randomize bir şekilde 30' lu 3 gruba ayrılmıştır. Ad libitum beslenen kontrol grubu, içme suyu içinde $\% 60$ konsantre fruktoz çözeltisi verilen fruktoz grubu ile içme suyu içinde $\% 60$ konsantre fruktoz çözeltisi ve ikişer haftalık aralıklarla parenteral demir uygulanan fruktoz-demir grupları çalışılmıştır. Tüm gruplara günlük eşit miktarda kalori verilmiştir. Íkişer haftalık aralıklarla (2., 4., 6., 8. ve 10. haftalarda) tüm gruplardan 5'er sıçana laparotomi uygulandıktan sonra karaciğer ve kan örnekleri alınarak biyokimyasal ve histopatolojik progress değerlendirilmiştir.

Bulgular: On haftalık çalışma sürecinde hiçbir grupta karaciğer yağlanması ve fibrozisi saptanmamıștır. Fruktozla beslenen sıçanlarda hepatosellüler balonlaşma skorları kontrol grubuna göre anlamlı yüksek bulunmuştur $(p<0.001)$. Fruktoz ve fruktoz-demir gruplarında kontrol grubuna göre serum AST ve ALT değerlerinde yükselme saptanmamıştır. Fruktoz-demir grubunda 10. haftada kontrol ve fruktoz gruplarına göre ferritin düzeyi anlamlı yüksek saptanmıştır $(p<0.001)$. Ayrıca histopatolojik olarak 4 . haftadan itibaren fruktoz-demir grubunda karaciğerde demir birikimi de saptanmıştır.

Sonuç: Genç ve dişi sıçanlarda \%60 konsantrasyonda fruktozlu içme suyuyla ve demir yüklemeyle 10 haftalık süreçte biyokimyasal ve histopatolojik steatohepatit modeli oluşturulamamıştır. Insan fenotipine yakın bir steatohepatit modeli oluşturabilmek için en az 16 haftalık bir süreyle yetişkin erkek sıçanlarda çalışılması, yeterli hidrasyon ve beslenmenin sağlanabilmesi için de fruktozun yemle kombine edilerek verilmesi daha uygun görünmektedir.
\end{abstract}

Anahtar Kelimeler: Hepatik Aşırı Demir Birikimi (HIO), Fruktoz, Non Alkolik Steatohepatit (NASH), Non Alkolik Yağıı Karaciğer Hastalığı (NAFLD)

\begin{abstract}
Aim: The aim of this study was to develop a fructose- and iron-mediated model of steatohepatitis, which is similar to the human phenotype.

Materials and Methods: We randomly divided ninety 1.5 months old female Wistar-Albino rats into three groups. All three groups contained 30 rats in each group and 5 subgroups per group. While the control group was fed ad libitum, the fructose group's feed consisted of $60 \%$ fructose in drinking water and that of the fructose-iron group consisted of $60 \%$ fructose in drinking water along with intraperitoneal administration of iron every 2 weeks. We performed laparotomies at 2-week intervals (at 2, 4, 6, 8, and 10 weeks) in all subgroups.

Results: None of the groups had hepatosteatosis or fibrosis at the end of the 10th week. Hepatocellular ballooning scores were significantly higher in the fructose-fed groups than in the control group $(p<0.001)$ At 10th week serum ferritin levels in the fructose-iron group were significantly higher than those in the control and fructose groups $(p<0.001)$. Iron accumulation in the rat liver was observed in the fructose-iron group histopathologically by the 4 th week.

Conclusion: Chemically and histopathologically, a model of steatohepatitis cannot be developed in young and female rats with $60 \%$ concentrated fructose feeding and administration of iron for 10 weeks. To develop a model of steatohepatitis resembling the human phenotype, it is more advisable and feasible to use adult male rats fed meals combined with fructose in order to maintain adequate hydration and nutrition for at least 16 weeks.
\end{abstract}

Key words: Experimental Animal Models, Fructose, Iron Overload, Non-alcoholic Fatty Liver Disease, Steatohepatitis

Cite this article as: Keskin M. Fructose- and Iron-Mediated Model of Steatohepatitis in Rats. Selcuk Med J 2020;36(3): 199-207 


\section{INTRODUCTION}

Steatohepatitis may result in severe morbidities like liver cirrhosis and hepatocellular carcinoma. The prevalence of the disease gradually increases and pathogenesis has not yet been explained completely. Current knowledge cannot adequately explain the etiopathogenesis because there is a lack of accurate therapy.

Nonalcoholic fatty liver disease (NAFLD) has a wide spectrum: in association with or without fibrosis and cirrhosis, fat accumulation in the liver without inflammation or fibrosis (hepatosteatosis) and fat accumulation accompanying necroinflammation (steatohepatitis) $(1,2)$. Nonalcoholic steatohepatitis (NASH) is a disease characterized by hepatosteatosis, hepatocellular ballooning, inflammatory infiltration, Mallory bodies, megamitochondria and fibrosis as in alcoholic liver disease. Although there is not yet a full consensus about minimally necessary findings for the diagnosis of NASH; hepatosteatosis, hepatocellular ballooning, mixed mononuclear cell infiltration and coexistence of focal necrosis is required for the histological diagnosis of NASH (3).

Despite continuing efforts to constitute a model of steatohepatitis in animals similar to the human phenotype, it is not yet fully established. In animal models, increased consumption of high-fructose diets may increase insulin resistance, which impairs glucose tolerance and causes hyperinsulinemia, hypertriglyceridemia, and hypertension as shown in various studies. However, many of these experimental studies have been performed using high doses of fructose. In humans, there is no evidence of similar effects of fructose with consumption of physiological amounts. Endocrine and metabolic data support that increased dietary fructose may cause increased body weight, adiposity, insulin resistance and conditions related to diabetes and metabolic syndrome, however this assumption is still unproven in wide-ranging epidemiological studies with humans. Recent studies have shown that high fructose consumption causes fat storage in the abdominal region and the risk of chronic disease rose faster than expected (4). Acute negative effects of high fructose consumption lead to an increase in fatty tissue and accelerates the intake of more energy and may accelerate the development of insulin resistance in individuals in the long-term (5).

Transition metals such as iron and copper are involved in a variety of physiological conditions in the oxidation step. The liver is the primary organ affected by iron overload (3). Iron overload in the body occurs in increased absorption of dietary iron, excessive vitamin $\mathrm{C}$ intake, during treatment with parenteral iron, hemoglobinopathies, pathological conditions such as hemolytic anemia and hemochromatosis (6). Why the iron accumulation causes hepatocellular damage is not precisely known but peroxidation of polyunsaturated fatty acids (PUFA) are thought to be the reason (7). Iron overload in hepatocytes enhances activation of phospholipase $\mathrm{A} 2$ and peroxidative damage occurs (8). Hepatic fibrosis and eventually cirrhosis develop (9).

In the present study, an experimental steatohepatitis model, which is very similar to human histological steatohepatitis formation, was investigated. In this experimental model, the intention is to combine fructose and iron in terms of their metabolic and free radical-forming properties. If a model of steatohepatitis is successfully developed in rats, many etiopathogenetic studies can be performed, which would aid in the development of therapy for steatohepatitis.

\section{MATERIALS AND METHODS}

The study was conducted in the Laboratory of Biochemistry and Pathology at Ege University Faculty of Medicine Experimental Research Center. Our study has been approved by the Ege University Faculty of Medicine Ethics Committee of Animal Experiments and was performed in accordance with the rules of the ethics committee. In this study, a number of 90, 6to 8-week-old female Wistar-Albino rats, weighing 39$128 \mathrm{~g}$ and reproduced at Ege University Experimental Animal Reproduction Center, were used. We kept all of the rats in a humid atmosphere of $50-60 \%$, at 12 hours' light and 22 to $24{ }^{\circ} \mathrm{C}$ room temperature conditions during the experiments. We placed 5 rats in each group with adequate amounts of drinking water, in separate cages and gave them standard rat chow. Rats were received 10 days before the study and they had a 10-day adaptation period.

\section{Creating Groups and Performing Tests}

Ninety Wistar-Albino rats were randomly divided into three groups. All three groups contained 30 rats in each group and 5 subgroups per group: 2 nd week group (5 rats), 4th week group (5 rats), 6th week group (5 rats), 8th week group (5 rats), and 10th week (10 rats). Initially, we planned to perform the study for a period of 12 weeks. However, due to an intake of high concentrated fructose as drinking water, high rates of morbidities and mortality occurred; to increase the power of statistical comparison of the most important 
groups of the 10th and 12th week we combined the 10th and 12th week groups to improve the success rate of statistical analysis of the experiment with 10 rats.

Group I (control, $n=30$ ): Rats were fed with standard chow and drank tap water; liver and serum samples were taken from 5 rats at two-week intervals $(2,4,6$, and 8 weeks) but 10 rats at 10 th week.

Group II (fructose, $n=30$ ): Rats had an equal amount of daily caloric chow as same as in the control group and drank 60\% concentrated fructose solution as drinking water; liver and serum samples were taken from 5 rats at two-week intervals $(2,4,6$, and 8 weeks) but 10 rats at 10 th week.

Group III (iron-fructose, $n=30$ ): Rats had an equal amount of daily caloric chow as same as in the control group and drank $60 \%$ concentrated fructose solution as drinking water. We also administered iron intraperitoneally at two-week intervals; liver and serum samples were taken from 5 rats at two-week intervals $(2,4,6$, and 8 weeks) but from 10 rats at the 10th week.

The renewal of chow and drinking water were prepared daily in the morning between 09:00-10:00 hours. At the beginning of the study, we recorded the initial weight measurements of the rats and continued every week sequentially. We performed iron injections and calorie calculations according to the current weight of the rats. Iron injections were performed intraperitoneally in the form of ferric polymaltose (Ferrum Haussmann; $100 \mathrm{mg}$ per ampules) diluted with saline (dosing $1 \mathrm{mg} / \mathrm{kg}$ ) at the 1st, 3rd, 5th, 7th and 9th weeks. Fructose and iron applications started simultaneously in all groups. All subgroups as described before were sacrificed with two-week intervals by anesthesia of ketamine $50 \mathrm{mg} / \mathrm{kg}$ and xylazine $10 \mathrm{mg} / \mathrm{kg}$ administered intraperitoneally.

\section{Liver and Blood Sampling}

We performed laparotomy with a midline incision under anesthesia. We sampled the maximum amount of blood from the inferior vena cava. Separated serum samples were analyzed on the same day for aspartate aminotransferase (AST), alanine aminotransferase (ALT), ferritin, and fasting serum glucose measurements. Right lobes of the liver were taken for histological examination.

\section{Storage and Preparation of Samples}

Blood samples were centrifuged at $3000 \mathrm{rpm}$ for 5 minutes. Serum was separated into portions and was kept in the freezer at $-80^{\circ} \mathrm{C}$. The right lobes of the liver were stored in $5 \%$ formaldehyde for histopathological examination.

\section{Histopathologic Analysis Methods}

After fixation of liver samples, we created paraffin blocks and 5- $\mu \mathrm{m}$ thickness sections. We processed the specimens for histopathological examination with hematoxylin and eosin (H\&E) and analyzed under the light microscope (the $\times 100$, the $\times 200$, and $\times 400$ magnification). In addition to routine staining in the liver tissues also iron deposits were stained with Prussian blue and evaluated. Histopathological samples were evaluated according to the Brunt criteria and total nonalcoholic fatty liver disease (NAFLD) score was calculated using the NASH Clinical Research Network Scoring System (10).

\section{Statistical Analysis}

Statistical analyses were done using computer software "Statistical Package for Social Sciences V.19.0" (IBM Corp., Armonk, NY, USA) for Windows. Continuous variables were expressed as mean \pm standard deviation. Normal distribution of the data was analyzed with one sample Kolmogorov-Smirnov test. For normally distributed parameters, one-way ANOVA test was used to test the significance of difference for more than two groups and Tukey's test was used for post hoc analysis. For non-normally distributed parameters, Kruskal Wallis test was used to test the significance of difference between more than two groups and intergroup comparisons were done using Mann-Whitney $U$ test. Statistical significance for all analyses was defined as $p<0.05$.

\section{RESULTS}

The study was started with 90 rats but completed with 78 rats due to unexpected death of 12 rats during the study period.

\section{Biochemistry Tests}

In addition to liver functions test as AST and ALT, fasting serum glucose (FSG) and ferritin levels were examined at weeks 2 nd, 4th, 6th, 8 th and 10th (Figure 1-4).

\section{Biochemistry Tests-2nd Week}

Although AST and ALT levels were significantly different between groups, FSG and ferritin levels were not significantly different. AST levels of the fructoseiron group were significantly lower than the control group $(p=0.021)$. ALT levels of fructose and fructoseiron groups were significantly lower than the control group.

\section{Biochemistry Tests - 4th Week}

Comparison between the groups showed a significant difference only for the ferritin levels. Ferritin 


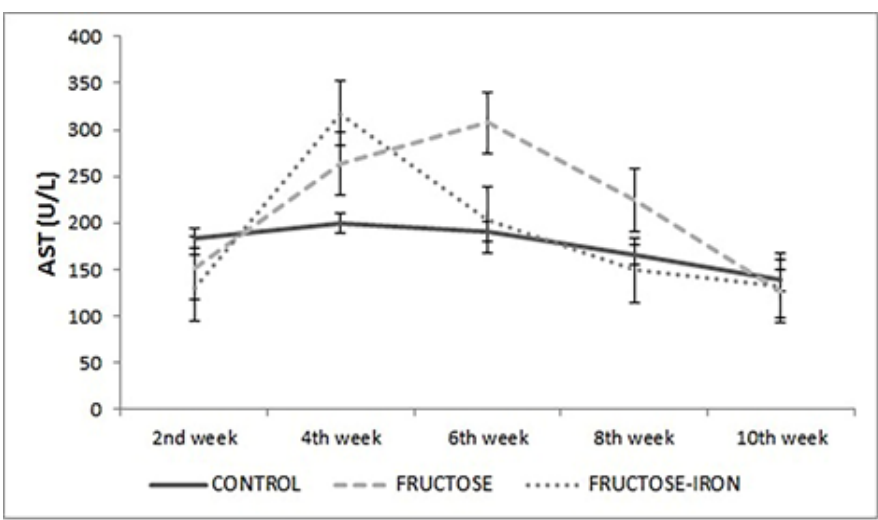

Figure 1. AST levels by weeks

levels of the fructose-iron group were significantly higher than both control and fructose groups $(p=0.008$ and $\mathrm{p}=0.018$ ).

\section{Biochemistry Tests - 6th Week}

Comparison of the groups showed a significant difference only for the FSG levels of control and fructose-iron groups. Fasting serum glucose levels of the fructose-iron group were significantly higher than the control group $(\mathrm{p}=0.032)$.

\section{Biochemistry Tests - 8th Week}

Comparison between the groups showed a significant difference for the ALT and ferritin levels. While ALT levels of the fructose-iron group were significantly lower than the control group $(p=0.03)$, ferritin levels were significantly higher than both the control and fructose groups (both $p<0.001$ ).

\section{Biochemistry Tests - 10th Week}

Comparison between the groups showed a significant difference for the ALT and ferritin levels. While ALT levels of the fructose-iron and fructose

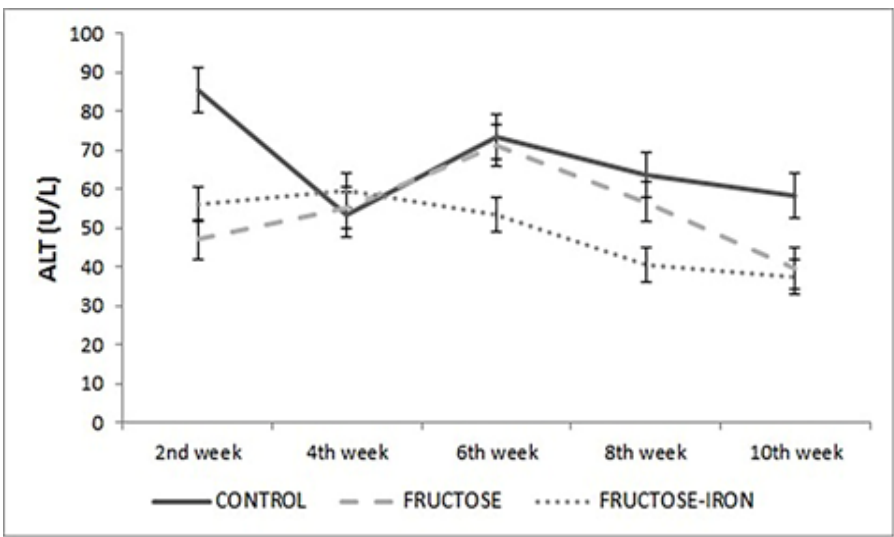

Figure 2. ALT levels by weeks

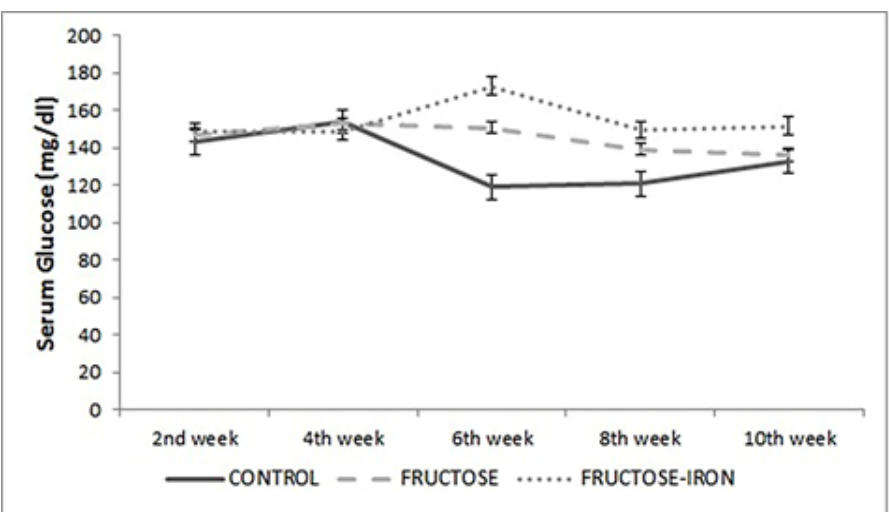

Figure 3. Fastening serum glucose levels by weeks

group were significantly lower than the control group $(p=0.001$ and $p=0.003)$, ferritin levels of the fructoseiron group were significantly higher than both the control and fructose groups (both $p<0.001$ ).

\section{Histopathologic Findings}

Histopathological steatohepatitis scores of liver samples were examined at weeks 2nd, 4th, 6th, 8th and 10th (Figure 5, 6).

\section{Histopathologic Findings-2nd Week}

While the comparison between the groups showed a significant difference for hepatocellular ballooning and NASH scores, there was no significant difference in scores of steatosis, lobular inflammation, fibrosis, and iron accumulation. Hepatocellular ballooning score and NASH scores of the fructose-iron group were significantly higher than the control group (both $\mathrm{p}=0.016)$.

\section{Histopathologic Findings - 4th Week}

While the comparison between the groups showed a significant difference for hepatocellular ballooning,

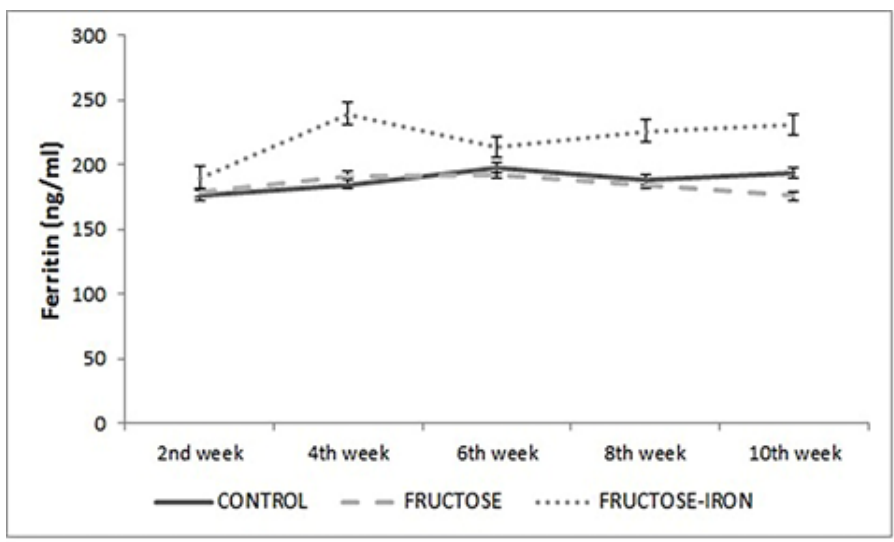

Figure 4. Ferritin levels by weeks 


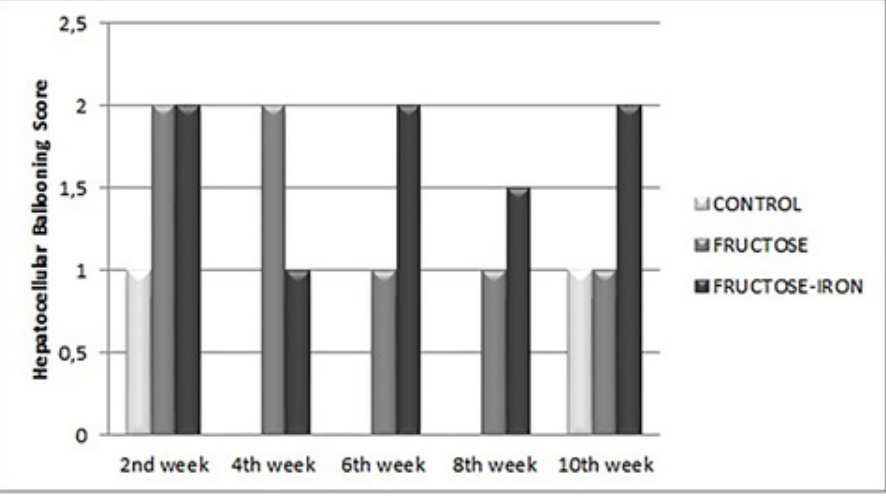

Figure 5. Median hepatocellular ballooning scores by weeks

iron accumulation and NASH scores, there was no significant difference in scores of steatosis, lobular inflammation, and fibrosis. A hepatocellular ballooning score of both the fructose and fructoseiron groups were significantly higher than the control group ( $p=0.008$ and $p=0.032)$. The NASH scores of the fructose group was significantly higher than the control group $(p=0.016)$. Iron accumulation in the fructose-iron group was significantly more than both the control and fructose groups (both $p=0.032$ ).

\section{Histopathologic Findings - 6th Week}

While the comparison between the groups showed a significant difference for hepatocellular ballooning, iron accumulation and NASH scores, there was no significant difference in scores of steatosis, lobular inflammation, and fibrosis. A hepatocellular ballooning score of both the fructose and fructose-iron groups was significantly higher than the control group $(p=0.032$ and $p=0.029)$. NASH score of the fructose-

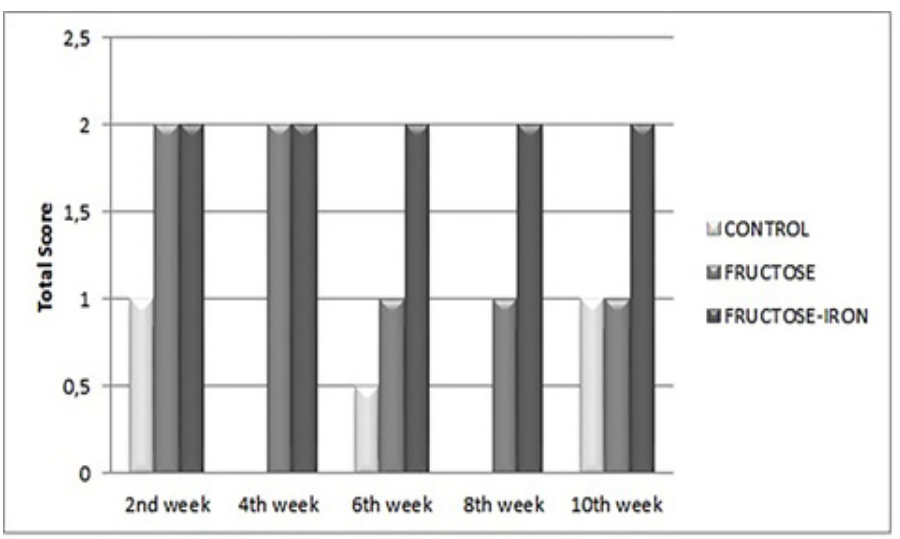

Figure 6. Total median scores by weeks

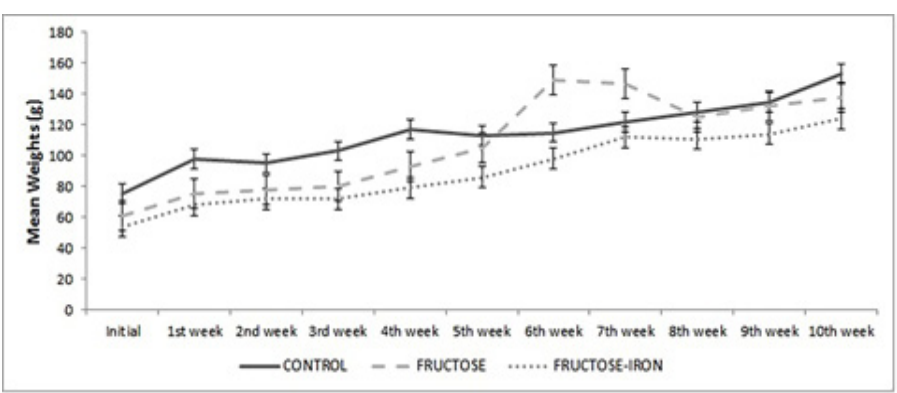

Figure 7. Mean weights of rats by weeks

iron group was significantly higher than the control group ( $p=0.029)$. Iron accumulation in the fructoseiron group was significantly more than both the control and fructose groups $(p=0.029$ and $p=0.016)$.

\section{Histopathologic Findings - 8th Week}

While the comparison between the groups showed a significant difference for hepatocellular ballooning and iron accumulation, there was no significant difference in steatosis, lobular inflammation, fibrosis, and NASH scores. In a comparison of subgroups, the hepatocellular ballooning score of the fructose group was significantly higher than the control group $(p=0.032)$.

\section{Histopathologic Findings - 10th Week}

While the comparison between the groups showed a significant difference for hepatocellular ballooning, iron accumulation and the NASH score; there was no significant difference in scores of steatosis, lobular

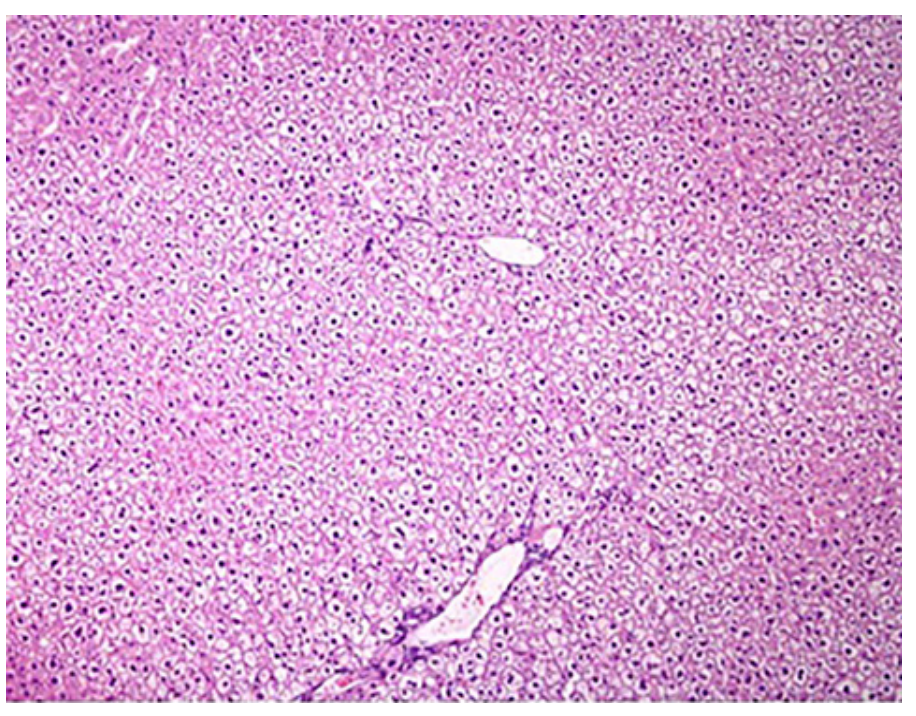

Figure 8. Fructose mediated hepatocellular ballooning in rat liver (H\&E X100) 


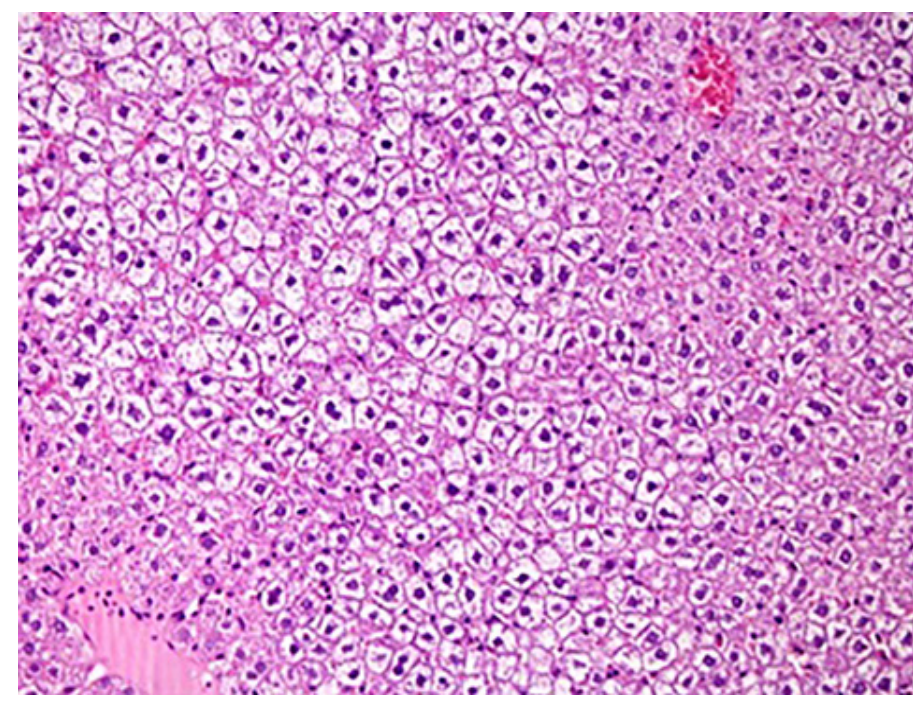

Figure 9. Fructose mediated hepatocellular ballooning in rat liver (H\&E x200)

inflammation, and fibrosis. Hepatocellular ballooning, iron accumulation and NASH score of the fructoseiron group were significantly higher than both control and fructose groups (respectively $p=0.027, p=0.027$ and $p<0.001)$. We depicted the weight course of the rats by weeks (Figure 7). Photos (Figure 8-10) show histopathological images.

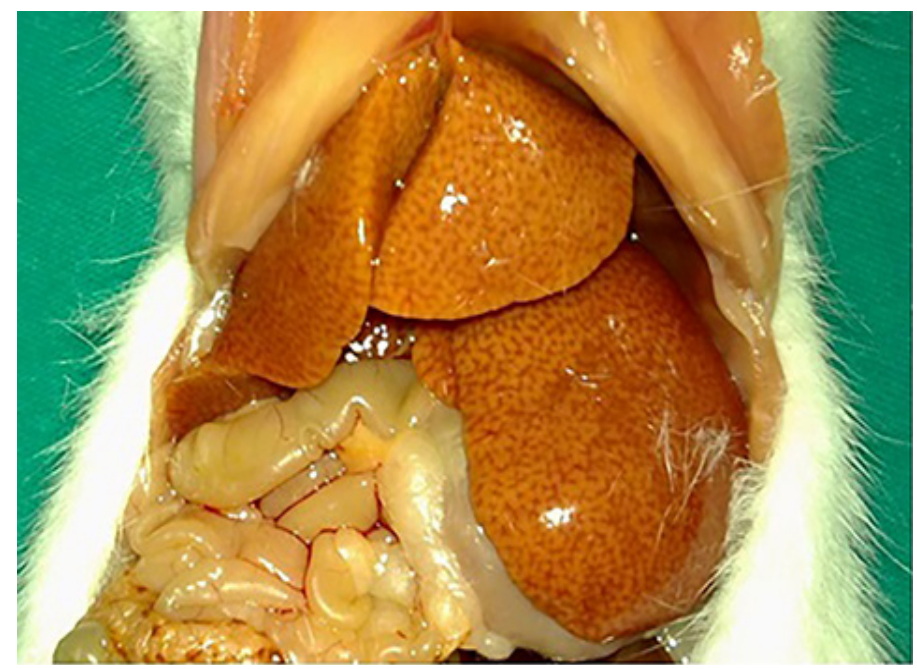

Figure 10. Macroscopic image of rat liver after fructose and iron intake at the 10th week

\section{DISCUSSION}

Despite continuing efforts to constitute a model of steatohepatitis in animals similar to humans, the model is not fully established yet. In the present study, we investigated an experimental steatohepatitis model that is very similar to the human histological steatohepatitis formation. Our results showed that chemically and histopathologically, it is not possible to constitute of a model of steatohepatitis in the young and female rats with $60 \%$ concentrated fructose feeding and administration of iron within 10 weeks; we only observed hepatocellular ballooning as a finding of hepatocyte injury in fructose groups. Liver damage presents as apoptosis, lytic necrosis, and ballooning in histopathological examinations. Hepatocellular ballooning is characterized by a hepatocyte injury with intracellular liquid sequestration, a decrease in density of hepatocyte cytoplasm and swelling due to other toxic causes (11). According to the literature, during the NASH process, while hepatocellular ballooning is establishing, significant disruptions and disturbances also occur in cellular structures such as intermediate cytoskeleton filaments, lipid droplets, and the endoplasmic reticulum, (12). Histopathological examination of fructose and fructose-iron groups, after the 4th week showed only hepatocellular ballooning without steatosis, inflammation and fibrosis. This histopathological finding indicates that hepatocellular ballooning alone is not adequate for progression to steatohepatitis.

Several studies have been done to evaluate the different types of high fructose diet on the liver. In these studies, fructose was used as multi-variable diets in the drinking water, fat-rich mixtures, free hexose, sucrose and the oil-rich corn syrup (13). Histologically a steatohepatitis model could be established in a mutant or non-mutant mice with methionine-cholinedeficient (MCD) diet, which causes macrovesicular steatosis, lobular inflammation, pericellular, and perisinusoidal fibrosis as mimicking severe NASH.

C57B16 mouse fed with high-calorie, substantially medium-chain saturated fatty acids and fructoserich diet had phenotypic obesity, insulin resistance, increased hepatic oxidative stress and most of all human NASH phenotype like steatosis with significant hepatic inflammation and marked fibrosis after 16 weeks (14). Ackerman et al. reported macrovesicular and microvesicular steatosis in Sprague-Dawley rats that fed with fructose-rich diet (60\% fructose) (15). Kawasaki et al. reported significant macrovesicular steatosis and interlobular inflammation in rat livers 
which fed for 5 weeks with fructose-rich diet $(70 \%$ fructose) (16). In the study performed by Armutcu et al., livers of Wistar-Albino rats that fed for 10 days with fructose enriched drinking water (10\%fructose) established macrovesicular and microvesicular steatosis but no inflammation (17). Fructose-rich diets are more suitable for NASH models rather than fat-rich diets (16). Different types of high-fructose diets have different metabolic effects, which suggest the involvement of genetic factors. The differences between species as well as depending on gender and age-related factors, metabolic side effects of fructose are less in females than males and also less in young people than elderly $(18,19)$. High fat and high fructose diet fed rat livers have increased iron accumulation, suggesting an underlying increased consumption of fructose similarly as in NAFLD patients' liver biopsy samples (20). To establish hepatic iron overload ( $\mathrm{HIO}$ ) in mouse models, iron supplement and intraperitoneal administration of iron can be used and clinically represents similarities with HIO (21). All these observations increase the suspicion of the contribution of fructose to NASH and show that fructose not only stimulates hepatic de novo lipogenesis but also does it by triggering inflammation in the liver.

According to the literature experimental models of fatty liver made by fructose is composed through a long process between 2 to 24 weeks $(17,22)$. A process of average at least 4-6 weeks should continue depending on the diet for the start of the findings in the liver as steatosis. As the duration of feeding increases the clinical findings changes from NAFLD to NASH but currently, there is not a suitable model of the natural pathogenesis of NASH. Existing models of $\mathrm{NASH}$ are formed in mutant subjects or in subjects fed with fat-rich, fructose-rich or MCD diets that are not physiological regimens. Current experimental models for NASH usually have single time zone therefore biochemical and histopathological changes and temporal interactions occurring during the course of NASH pathogenesis cannot be evaluated in these models.

In the current study we intended to create a model like human NASH phenotype; therefore, we studied in non-mutant Wistar-Albino rats. The daily intake total amount of energy was equal in both the fructose and control groups to achieve a metabolic balance between the groups in order to exclude the steatosis due to a high-energy intake. We did an examination of all groups at two-week intervals to be able to identify the initial term and progression of steatosis and then the when and how the development of findings of expected NASH started.

NASH patients have higher levels of transaminases than normal however in the present study AST and ALT levels were low (no statistical difference) compared to the control group in fructose and fructose-iron groups in all sections which are exactly an opposite situation than expected. Since there is no literature data known that fructose or iron has an effect of reducing the transaminase levels it is considered to be clinically irrelevant. Moreover, at the end of 10 weeks, the inability to obtain an expected ALT elevation in the fructose and fructose-iron groups suggests that the model of NASH has not been established.

Measurement of insulin and fasting serum glucose levels was planned to determine the metabolic effects of fructose but insulin levels could not be measured for technical reasons; we were only able to measure and record the fasting serum glucose levels. During the follow-up only at the 6th week, FPG levels of the fructose-iron group were higher than the control group $(p=0,038)$; these findings suggest that the expected insulin resistance has not been established, therefore adequate metabolic dysfunction and as a first step of steatohepatitis, hepatic insulin resistance have not been established in the fructose and fructose-iron groups.

In our study, fructose feeding in drinking water, especially when administered at a high concentration such as a $60 \%$ fructose, after 2 weeks resulted in a decrease in fluid intake of rats and consequently led to partial dehydration, therefore adequate nutrition and hydration could not have been achieved. This condition resulted in growth retardation of the rats and also the desired increase in body mass couldn't be reached. As stated before, initially, we planned to perform the study for a period of 12 weeks. However, due to the intake of high concentrated fructose, high rates of morbidities and mortality occurred. To increase the power of statistical comparison of the most important groups of the 10th and the 12th week we combined the 10th and 12th week groups to improve the success rate of statistical analysis of experiment with 10 rats. Nevertheless, it is more feasible that a process will need at least 16 weeks in order to create an ideal model of steatohepatitis. Pellets combined with fructose for feeding in order to ensure adequate hydration and nutrition in rats seems more appropriate.

Younger age and female gender are negative 
factors to establish a model of steatohepatitis in rats $(18,19)$. NAFLD development probability significantly increases with body mass index in a direct proportion (23). Therefore, we conclude that it is more difficult to develop steatohepatitis in young and female rats with lower body mass indices. However, in our study, the age and gender of the rats are considered as negative factors to establish NASH models.

To check whether the adequate HIO levels have been achieved or not, ferritin levels were monitored in the groups. According to our results, it is possible to postulate that adequate $\mathrm{HIO}$ is achieved since ferritin levels of the fructose-iron group was significantly higher than both control and fructose groups at 8th and 10th weeks $(p<0.001)$. This iron overload was also confirmed in the iron-fructose group with histopathological results starting in the 4th week and beyond. Therefore, in the fructose-iron group, oxidative stress and inflammation symptoms associated with excess iron accumulation should be expected. In spite of the failure to obtain sufficient steatosis with fructose, iron overload is achieved, but it is thought that we could not obtain the effects and oxidative stress of iron overload-associated inflammation. In other words, if we could have adequate steatosis with fructose to provide the first step in the pathogenesis of NASH (insulin resistance and steatosis) oxidative stress and associated effects of iron accumulation could be detected (24).

In conclusion, current study has shown that, chemically and histopathologically a model of steatohepatitis could not be constituted in young, female rats fed with $60 \%$ concentrated fructose in drinking water for 10 weeks. We observed some histopathological changes such as hepatocellular ballooning in liver samples of fructose fed rats showing that fructose-induced liver damage has occurred to some extent. However, progression to steatohepatitis did not occur in these rats indicating that hepatocellular ballooning alone is not sufficient for the development of $\mathrm{NASH}$. Histopathological examinations of rat livers revealed that significant iron accumulation begins at 4th weeks by intraperitoneal administration of iron. To constitute a model of steatohepatitis similar to the human phenotype, it is more advisable and feasible to study with adult male rats fed by meals combined with fructose in order to maintain adequate hydration and nutrition within at least 16 weeks of a period or more.

Conflict of interest: Author declares that there is no conflict of interest between the authors of the article.

Financial conflict of interest: Author declares that he did not receive any financial support in this study.

Address correspondence to: Muharrem Keskin, Necmettin Erbakan University, Meram Faculty of Medicine, Department of Gastroenterology, Konya, Turkey

Tel: +905552242474

e-mail: muharrem.keskin@gmail.com

\section{REFERENCES}

1. Matteoni CA, Younossi ZM, Gramlich T, et al. Nonalcoholic fatty liver disease: A spectrum of clinical and pathological severity. Gastroenterology 1999;116:1413-9.

2. Falck-Ytter $Y$, Younossi ZM, Marchesini G, et al. Clinical features and natural history of nonalcoholic steatosis syndromes. Semin Liver Dis 2001;21:17-26.

3. Angulo $P$, Lindor KD. Non-alcoholic fatty liver disease. J Gastroenterol Hepatol 2002;17 Suppl:S186-90.

4. Stanhope KL, Havel PJ. Fructose consumption: Potential mechanisms for its effects to increase visceral adiposity and induce dyslipidemia and insulin resistance. Curr Opin Lipidol 2008;19:16-24.

5. Elliott SS, Keim NL, Stern JS, et al. Fructose, weight gain, and the insulin resistance syndrome. Am J Clin Nutr 2002;76:91122.

6. Hoffman R, Benz EJ, Shattil SJ, et al. Hematology: Basic principles and practice. In: Brittenham GM, ed. Disorders of iron metabolism: Iron deficiency and overload. 3rd ed. New York: Churchill Livingstone; 2000:397-428.

7. Hershko C, Link G, Cabantchik I. Pathophysiology of iron overload. Ann NY Acad Sci 1998;850:191-201.

8. Beckman JK, Borowitz SM, Burr IM. The role of phospholipase a activity in rat liver microsomal lipid peroxidation. J Biol Chem 1987;262:1479-84.

9. Bataller R, Brenner DA. Liver fibrosis. J Clin Invest 2005;115:209-18.

10. Brunt EM, Janney CG, Di Bisceglie AM, et al. Nonalcoholic steatohepatitis: A proposal for grading and staging the histological lesions. Am J Gastroenterol 1999;94:2467-74.

11. Burt AD, Mutton A, Day CP. Diagnosis and interpretation of steatosis and steatohepatitis. Semin Diagn Pathol 1998;15:246-58.

12. Lackner C. Hepatocellular ballooning in nonalcoholic steatohepatitis: The pathologist's perspective. Expert Rev Gastroenterol Hepatol 2011;5:223-31.

13. Bizeau ME, Pagliassotti MJ. Hepatic adaptations to sucrose and fructose. Metabolism 2005;54:1189-201.

14. Kohli R, Kirby M, Xanthakos SA, et al. High-fructose, medium chain trans fat diet induces liver fibrosis and elevates plasma coenzyme Q9 in a novel murine model of obesity and nonalcoholic steatohepatitis. Hepatology 2010;52:934-44.

15. Ackerman Z, Oron-Herman M, Grozovski M, et al. Fructoseinduced fatty liver disease: Hepatic effects of blood pressure and plasma triglyceride reduction. Hypertension 2005;45:1012-8.

16. Kawasaki T, Igarashi $K$, Koeda $T$, et al. Rats fed fructoseenriched diets have characteristics of nonalcoholic hepatic steatosis. J Nutr 2009;139:2067-71.

17. Armutcu F, Coskun O, Gurel A, et al. Thymosin alpha 1 
attenuates lipid peroxidation and improves fructose-induced steatohepatitis in rats. Clin Biochem 2005;38:540-7.

18. Horton TJ, Gayles EC, Prach PA, et al. Female rats do not develop sucrose-induced insulin resistance. Am J Physiol 1997;272(5 Pt 2):R1571-6.

19. Chevalier M, Wiley JH, Leveille GA. The age-dependent response of serum triglycerides to dietary fructose. Proc Soc Exp Biol Med 1972;139:220-2.

20. Wapnir RA, Devas G. Copper deficiency: Interaction with high-fructose and high-fat diets in rats. Am J Clin Nutr 1995;61:105-10.

21. Tsuchiya $H$, Akechi $Y$, Ikeda $R$, et al. Suppressive effects of retinoids on iron-induced oxidative stress in the liver. Gastroenterology 2009;136:341-50.
22. Matsuzawa N, Takamura T, Kurita S, et al. Lipid-induced oxidative stress causes steatohepatitis in mice fed an atherogenic diet. Hepatology 2007;46:1392-403.

23. Haslam DW, James WP. Obesity. Lancet 2005;366:1197209.

24. Abdelmalek MF, Diehl AM. Nonalcoholic fatty liver disease as a complication of insulin resistance. Med Clin North Am 2007;91:1125-49. 